УДК 340.115

DOI https://doi.org/10.32837/apdp.v0i90.3204

\title{
С.В.Білозьоров
}

\section{МЕТОДОЛОГІЧНЙ ПІДХІД ЯК ІНСТРУМЕНТ ПІЗНАННЯ ПРАВА}

Постановка проблеми. Від часу проголошення незалежності в Україні здійснено цілу низку важливих кроків щодо переформатування юридичної (правничої) науки у відповідності з потребами практики, формування власної моделі юриспруденції, якаб забезпечила відповідні умови для національного державотворення, культурного відродження правових звичаїв та традицій українського народу. Сьогодні розвиток юридичної (правничої) науки обумовлений інтеграційними та глобалізаційними процесами, що відбуваються в Європі та світі, ï̈ переходом від методологічного монізму до світоглядно-методологічного плюралізму. Це викликає необхідність концептуального перегляду традиційних уявлень про державно-правові закономірності та поглибленого осмислення ролі правознавства у сучасному суспільстві.

Теоретико-правовий аналіз усіх державно-правових явищ, визначення принципових орієнтирів подальшого розвитку юридичної (правничої) науки є важливими напрямами наукових досліджень, основою яких виступає методологія правознавства. Тому формування ефективної методологічної системи є першочерговим завданням для сучасної юриспруденції.

Актуальність теми дослідження зумовлена як тими процесами, які відбуваються у правовій реальності сучасних країн світу та України, зокрема, глобалізацією, гуманізацією, інтеграцією у міжнародне й європейське право, становленням і розвитком громадянського суспільства, формуванням національної правової доктрини, так і потребами їх філософсько-правового осмислення, розробки обгрунтованих перспектив подальшого розвитку правової системи України.

Аналіз останніх досліджень і публікацій. Проблема удосконалення методології сучасного правознавства є вельми актуальною і потребує ретельного дослідження, хоча їй приділяли увагу багато дослідників, зокрема у працях В.Д. Бабкіна, Ю.М. Бондаря, С.Д. Гусарєва, О.В. Зайчука, М.С. Кельмана, Д.А. Керімова, М.I. Козюбри, О.Л. Копиленка, М. В. Костицького, Л.О. Луць, В.С. Нерсесянца, Ю.М.Оборотова, В.В.Оксамитного, Н.М.Оніщенко,А.В.Полякова, П.М.Рабіновича, В.М.Селіванова, О.Ф.Скакун, О.Д.Тихомирова,Ю.С.Шемшученка таінших вчених.

Метою статті $\epsilon$ виокремлення реального стану і тенденцій розвитку методології правознавства, а також здійснення теоретико-правової характеристики використання методологічних підходів у сучасних юридичних дослідженнях.

Виклад основного матеріалу дослідження. Реалізація методологією права свого призначення у системі юридичних (правничих) наук можлива, у першу чергу, на основі виокремлення таких засад здійснення юридичних наукових досліджень, які визначають їх «орієнтири», пріоритетні ракурси та «формати» наукових розвідок правової реальності, впливу права на формування суспільного порядку в його єдності та взаємодії з іншими соціальними регуляторами. Проте гносеологічна та епістемологічна проблематика права сьогодні ще досить обмежено представлена

(ㄷ) Є. В. Білозьоров, 2021 
у вітчизняній юридичній науці, оскільки правові дослідження здебільшого спрямовані на постановку та вирішення онтологічних питань правової реальності.

Зважаючи на те, що досить тривалий час методологічна традиція вітчизняної юридичної науки формувалася та розвивалася переважно на засадах моністичного праворозуміння, зокрема, домінування позитивізму, що і викликає потребу в переосмисленні державно-правових явищ.

Методологія сучасних правових досліджень характеризується такими ознаками як охоплення різних форм теоретичного пізнання державно-правової дійсності, оптимізацією пізнавального інструментарію, впливовістю на рівень розвитку юридичної (правничої) науки у цілому, зумовленістю світоглядними, філософськими та наукознавчими підвалинами правознавства XXI ст.

Сучасна юридична практика вимагає від юриспруденції постійного вдосконалення її методології. В умовах сьогодення для юридичної (правничої) науки необхідно постійне здійснення їі оновлення методологічного знаряддя. Успіх вирішення теоретичних та практичних питань залежить від наявності та ступеня розробленості методологічних інструментів юридичної (правничої) науки. За їх відсутності дослідницька діяльність виявляється даремною, що не відповідає поставленим цілям [1, с. 14]. Результати наукової активності є наслідком не лише того, хто діє або на що спрямовано пізнавальну діяльність, а й того, яким методологічним інструментарієм здійснюється пізнавальний процес [2, с. 210].

До фундаментальних проблем юридичної (правничої) науки під кутом зору демократичної трансформації українського суспільства належить розроблення методології юридичних досліджень, об'єктивне вивчення історичного досвіду у галузі державно-правового будівництва. Істотного оновлення потребує методологія вітчизняного правознавства у напрямі наближення до найбільш вагомих загальновизнаних досягнень європейської та світової наукової думки [3, с. 6].

Нині є всі підстави стверджувати, що найважливішим досягненням у розробці методологічних проблем у правовій науці України є шлях утвердження як світоглядних орієнтирів основних загальнолюдських цінностей - засад демократичної, правової, соціальної держави, соціальної справедливості, гуманізму, поваги до людської гідності, прав і свобод людини та громадянина. У цьому ракурсі постає завдання щодо переходу наукових юридичних досліджень на сучасні методологічні орієнтири, які знайшли своє закріплення в чинній Конституції України та відповідають демократичним принципам Українського народу.

Необхідно зазначити, що методологія правознавства (юридичної науки) - це вчення про структуру, логічну організацію, принципи, методи, засоби та форми діяльності дослідника у процесі пізнання ним державно-правових явищ. Методологія юридичної (правничої) науки забезпечує як наукове пізнання, так і наукову діяльність учених-юристів. Методологія правознавства повинна мати чітку структуру (вертикальну та горизонтальну), що охоплює загальні компоненти в різних відносинах між ними: домінуючий світогляд, тип наукового мислення, філософські й інші підстави, загальнонаукові та спеціально-наукові парадигми, методологічні підходи, теорії та інші наукові знання, потенційно можливі й використовувані методи [4, с. 10, 23]. 
Сучасний стан науки в Україні характеризуються переходом від уніфікованої, єдино дозволеної, «одержавленої» методології до різноманітних методологічних засад, парадигм, підходів, що поширюється на вітчизняне правознавство. Демонополізація або "роздержавлення» методології - безперечно плідний процес, який збагачує, демократизує пошуки істини, вивільняє та стимулює дослідницьку енергію, дозволяє повно та всебічно осягнути предмет дослідження - специфічні державно-правові закономірності функціонування держави та права. Уже сьогодні можна зафіксувати позитивні результати цієї методологічної тенденції, що втілені, зокрема, в переосмисленні «класичних» і запровадженні нових понять вітчизняного загальнотеоретичного правознавства.

Водночас перехід від методологічного монізму до світоглядно-методологічного плюралізму поряд із безперечними позитивними наслідками часто призводить до еклектичного поєднання різних світоглядних позицій, що зрештою породжує суперечності, які не узгоджуються з вимогами науковості. Одне із завдань сучасної юридичної науки - остаточне подолання цієї кризи, надання вченню про методологію правознавства системності та стабільності.

Протягом останнього століття методологія від класичної, побудованої на раціональних та об'єктивних підходах, через некласичну (з її свободою вибору й суб’єктивністю), перейшла до посткласичної (постмодерністської), яка характеризується визнанням нераціонального та плюралістичного підходів. Необхідність використання постмодерністської методології зумовлюється неможливістю пояснити багато проблем правового та державного життя, керуючись підходами класичної й некласичної методології.

Більш того, в умовах ефективної взаємодії правової держави і громадянського суспільства складно усвідомити й інтерпретувати правові та державні реалії лише в межах одного методу, виникає потреба в поєднанні методологічних підходів, використання принципу додатковості, коли підходи й методи, доповнюючи один одного, забезпечують виведення нових продуктивних знань про правову та державну реальність [5, с. 290]. Окрім того, на зміну ідеологічним стандартам, що панували у вітчизняній методології майже все XX ст., прийшла деідеологізація. На сучасний час важливого ідеологічного значення набуває орієнтація на загальнолюдські цінності, дотримання принципів гуманізму, поваги до людської гідності, свободи, справедливості, взаємної відповідальності держави та особи [6, с. 11].

Засадами постнеокласичної методології юриспруденції є розробки світоглядно-філософської думки, в царині якої постійно конкурують різноманітні напрями. Визначальною особливістю світоглядної ситуації нашої епохи є визнання діалогічності та поліфонічності процесу пізнання державно-правових явищ. Усе це надає потужний імпульс для появи нових та оновлення традиційних підходів, що застосовуються у правових дослідженнях, котрі дозволяють усебічно розкрити різноманітні ракурси такого складного та багатоаспектного явища як право [7, с. 640].

Методологія сучасних правових досліджень характеризується такими ознаками: по-перше, вона не обмежується лише власне науковими методами, а охоплюе інші форми теоретичного пізнання державно-правової дійсності; по-друге, змістова наповненість та оптимальність методології теоретичних правових студій залежить від рівня розвитку юридичної (правничої) науки, відповідних йому норм 
і критеріїв оцінки науковості їх результатів; по-третє, для сучасної теорії права як юридичної наукової дисципліни притаманне визнання її зумовленості світоглядними, філософськими та наукознавчими підвалинами юридичної (правничої) науки XXI ст., новітньою науковою картиною світу права, тенденціями розвитку останнього [8, с. 248-249].

Основною складовою методології сучасного правознавства, на нашу думку, визначальною за евристичним потенціалом, є методологічні підходи. На переконання С.В. Бобровник, методологічний підхід - це сукупність знань про процес наукового дослідження, а метод - це лише сукупність способів і засобів пізнання об’єкта дослідження [9, с. 13-14].

Зі свого боку, М.М. Тарасов зазначає, що методологічний підхід у юриспруденції - це бачення певного ракурсу дослідження, шляхом сприйняття відповідних засобів мислення або у формі цілісної системи, або у вигляді окремих конструкцій, дослідницьких рамок і принципів для вирішення власне наукових завдань і проблем; спосіб «помислити» об'єкт [10, с. 234].

Плідною в цьому ж ракурсі є позиція О.Ф. Скакун, яка вважає, що методологічний підхід виявляє себе тоді, коли необхідно залучити в юриспруденцію методологічні засоби як філософського та метанаукового рівнів (загальна теорія систем, теорія моделювання, загальна теорія діяльності тощо), так й інших наук, які «працюють» на принципову методологічну орієнтацію наукового дослідження [11, с. 214].

Зважаючи на гомогенність структури підходу та основ науки, які мають три взаємозалежні рівні (світоглядний, теоретичний, інструментальний або методичний), М.С. Кельман пропонує визначати методологічний підхід як комплексний алгоритм осмислення дійсності, що виникає в результаті поєднання «фундаментальних ідей» і певних методів, тобто як специфічну єдність світоглядного, теоретичного і методичного знання, в якій головним є визначений суб'єктом пізнання порядок поєднання теорії та методу [4, с. 14]. Методологічний підхід є одним із основних компонентів парадигми та розглядається як сукупність взаємозалежних наукових методів. Він об'єднує різноманітні методи, певним чином пов'язані між собою, серед яких одні або кілька є основними, а всі інші підпорядковуються їм та мають допоміжний характер [12, с. 66].

Не можемо не виділити інтерпретацію I.А. Сердюка стосовно дослідження методологічного підходу та визначення автором теоретичних положень, що стали основою його гносеологічної розвідки. Так, цілком слушно дослідник зазначає, що термін "підхід» використовується сучасним правознавством у неоднакових значеннях і фактично без наведення його дефініції та визначення меж та правил його застосування; при цьому методологічний підхід має відносно автономний характер у структурі методології правознавства, а відтак, вирізняється від інших елементів методології таких як принципи пізнання та методи дослідження. На думку науковця, методологічний підхід слід розглядати як єдність філософського (світоглядного), теоретичного і методологічного знання, що постулює загальну стратегію дослідження; відбір досліджуваних фактів та інтерпретацію його результатів i, з урахуванням визначеного ракурсу досліджуваного об'єкта, різниться за своїм змістом [13, с. 53-57]. 
На сучасному етапі розвитку правничої науки уявляється за доцільне використовувати не окремо взятий підхід до дослідження правової дійсності, а їх певну сукупність, що сприятиме вирішенню різнопланових дослідницьких проблем (аксіологічний, антропологічний, діяльнісний, системний, феноменологічний, функціональний та інші) [14, с. 127]. Таке комплексне застосування методологічних підходів є фактором виконання вимог принципу усебічності та повноти наукового пізнання.

Не можна також не відзначити те, що соціокультурна природа права багато у чому впливає на обрання того чи іншого дослідницького підходу. У свою чергу, чинниками цього є і світоглядні установки дослідника, його прихильність до певної ідеології. Так, наприклад, науковці в межах радянської держави та вчені західної правової культури, досліджуючи право, акцентували увагу на різних його аспектах: якщо перші не зважали на аксіологічний підхід, до другі не могли його не використовувати, зважаючи на те, що у праві відображено основні цінності суспільства.

Висновки. Отже, в умовах сьогодення існує необхідність виокремлення у структурі методології правознавства дослідницьких підходів, які впливають на визначення стратегію дослідження та акцентують увагу дослідника на окремому ракурсі предмету пізнання. При цьому підхід є самостійним елементом гносеологічного інструментарію сучасної юридичної (правничої) науки, хоча і потребує комплексного використання одночасно з іншими методологічними елементами.

\section{Jimepamypa}

1. Демидов А.И. О методологической ситуации в правоведении. Правоведение. 2001. № 4. С. 14-22.

2. Скакун О.Ф. Теорія держави і права : підруч. Харків : Консум, 2006. 656 с.

3. Бабкін В.Д., Шемшученко Ю.С. Юридична наука України на сучасному етапі. Правова держава. 2005. Вип. 16. С. 5-9.

4. Кельман М.С. Методологія сучасного правознавства: становлення та основні напрями розвитку : автореф. дис. ... докт. юрид. наук : 12.00 .01 . Київ, 2013. 35 с.

5. Обротов Ю.М. Традиції та новації в правовому розвитку: загальнотеоретичні аспекти : дис. ... доктора юрид. наук : 12.00.01. Одеса, 2003. 379 с.

6. Пархоменко Н.М. Джерела права: проблеми теорії та методології : монографія. Київ : Юридична думка, 2008. $336 \mathrm{c.}$

7. Фальковський А. Методологія сучасної юриспруденції: аксіологічні та антропологічні засади. Антропологія права : філософський та юридичний виміри (стан, проблеми, перспективи) : статті учасників Міжнар. круглого столу (м. Львів, 3-5 груд. 2010 р.). Львів : Галицький друкар, 2010. С. 634-644.

8. Тихомиров А.Д. Юридическая компаративистика : философские, теоретические и методологические проблемы : монография. Киев : Знання, 2005. $334 \mathrm{c.}$

9. Бобровник С.В. Компроміс і конфлікт у праві : антрополого-комунікативний підхід до аналізу : монографія. Київ : Юридична думка, 2011. 384 с.

10. Тарасов Н.Н. Методологические проблемы юридической науки : монография. Екатеринбург : Изд-во Гуманитар. ун-та, 2001. 265 с.

11. Скакун О.Ф. Методологічний підхід і метод у порівняльному правознавстві : їхне співвідношення. Про українське право. 2009. Час. IV. С. 210-219.

12. Гусарєв С.Д., Тихомиров О.Д. Юридична деонтологія (Основи юридичної діяльності) : навч. посіб. 3-тє вид., перероб. і доп. Київ : Знання, 2008. 495 с.

13. Сердюк І.А. Інтерпретація поняття «методологічний підхід» у сучасній правничій науці. Hayковий вісник Дніпропетровського державного університету внутрішніх справ. 2018. № 4. С. 52-58.

14. Білозьоров Є.В. Місце та роль діяльнісного підходу в юридичній науці. Тринадцяті юридичні читання. Українська державність : крізь призму часу (до 100 річчя Української національно-демократичної революиії 1917-1921 pp.) : матеріали Міжнар. наукової конференції (м. Київ, 24-25 травня 2018 р.). Київ : Вид-во НПУ імені М. П. Драгоманова, 2018. С. 125-128. 


\section{Анотація}

Білозьоров С. В. Методологічний підхід як інструмент пізнання права. - Стаття.

У статті автор охарактеризовує ключові методологічні (дослідницькі) підходи, які використовуються в сучасних юридичних дослідженнях. Зазначається, що особливістю юридичної науки порівняно з іншими гуманітарними науками $є$ те, що вона має прикладний характер, покликана обслуговувати практичні потреби правого регулювання суспільних відносин, сприяти вдосконаленню чинного законодавства та юридичної практики.

У дослідженні уточнено, що ефективне розв'язання проблем демократичної трансформації українського суспільства, зокрема формування соціальної правової держави, національної системи права і законодавства, об'єктивно зумовило зростання ролі правознавства, яке повинно стати основним інтелектуальним чинником забезпечення державно-правових процесів в Україні. Обгрунтовано, що для всебічного дослідження предмету пізнання, з'ясування його сутності, якісних характеристик, динаміки розвитку в усій різноманітності об'єктивної реальності, її закономірних та випадкових проявів, властивістю ефективно і швидко реагувати на зміни у сучасному швидкоплинному житті, юридична наука повинна розвивати й удосконалювати систему методологічних підходів своїх досліджень. Очевидно, що ця система у сукупності з іншими спеціальними засобами і прийомами пізнання державно-правових явищ є складним утворенням, що формує дослідницький інструментарій юридичної науки - ¥ї методологію.

Дослідником визначено, що методологічні підходи є визначальною за евристичним потенціалом складовою (рівнем) методології дослідження державно-правових явищ сучасності. Методологічні (дослідницькі) підходи безпосередньо залежать від наукових парадигм і здебільшого є результатом їх використання, крім того, цей вплив здійснюється не лише за допомогою ідеалів, норм, правил, але й їх предметних положень. Вони об'єднують різноманітні методи, певним чином пов'язаних між собою, серед яких один або кількає основними, а всі інші підпорядковуються їм та мають допоміжний характер.

Автор узагальнив, що на сучасному етапі розвитку юридичної науки уявляється за доцільне використовувати не окремо взятий підхід до дослідження правової дійсності, а їх певну сукупність, що сприятиме вирішенню різнопланових дослідницьких проблем і практичних завдань щодо формування в Україні сучасної демократичної, соціальної та правової держави.

Ключові слова: методологічний інструментарій, методологічні підходи, методологія сучасних юридичних досліджень, наукова парадигма, юридична наука.

\section{Summary}

Bilozorov Ye. V. Methodological approach as a tool of knowledge of law. - Article.

In the article the author describes the key methodological (research) approaches used in modern legal research. It is noted that the peculiarity of legal science in comparison with other humanities is that it has an applied nature, designed to serve the practical needs of legal regulation of social relations, to improve the current legislation and legal practice.

The study clarifies that the effective solution of the democratic transformation of Ukrainian society, in particular the formation of the social rule of law, the national legal system and legislation, objectively led to the growing role of jurisprudence, which should become the main intellectual factor in state law in Ukraine. It is substantiated that for a comprehensive study of the subject of knowledge, clarifying its essence, qualitative characteristics, dynamics of development in all the diversity of objective reality, its natural and random manifestations, the ability to respond effectively and quickly to changes in modern fleeting life, legal science must develop and improve the system of methodological approaches to their research. It is obvious that this system in combination with other special means and methods of cognition of state and legal phenomena is a complex formation that forms the research tools of legal science - its methodology.

The researcher determined that methodological approaches are a defining component of the heuristic potential of the methodology of research of state and legal phenomena of today. Methodological (research) approaches directly depend on scientific paradigms and are mostly the result of their use, in addition, this influence is carried out not only through ideals, norms, rules, but also their substantive provisions. They combine various methods, in some way related to each other, of which one or more are basic, and all others are subordinate to them and have a supporting character.

The author generalizes that at the present stage of development of legal science it is expedient to use not a separate approach to the study of legal reality, but a certain set of them, which will help solve various research problems and practical problems of forming a modern democratic, social and legal state in Ukraine.

Key words: methodological tools, methodological approaches, methodology of modern legal research, scientific paradigm, legal science. 